\title{
The Law of Responsibility and the World Health Organisation: A Case Study on the West African Ebola Outbreak
}

\author{
Mark Eccleston-Turner and Scarlett McArdle
}

\begin{abstract}
The delay between the WHO being made aware of the 2014 Ebola epidemic in West Africa and declaring it a Public Health Emergency of International Concern (PHEIC) has been the subject of some considerable criticism in the literature, as well as in the Report of the Ebola Interim Assessment Panel commissioned by the WHO, which stated that that 'significant and unjustifiable delays occurred in the declaration of a Public Health Emergency of International Concern (PHEIC) by WHO.' This paper examines this late declaration of a PHEIC for Ebola through the lens of the law of responsibility, arguing that the WHO incurs responsibility for this delay. The law of responsibility is long standing in international law as the framework for providing redress for breaches of law. It gives rise to an obligation to provide redress and ensures some form of culpability for a breach of international law. In this paper we argue that the WHO does not merely have the power to declare a PHEIC via the International Health Regulations (2005), but also has a legal obligation to do so when the criteria are met. An obligation which we argue, they breached in failing to declare the recent Ebola outbreak in West Africa a PHEIC in a timely manner. This breach should then engage the law of responsibility for the consequences of the delay. The paper argues, however, that there exist substantial issues with the application of the principles of responsibility to international organizations.
\end{abstract}

Keywords WHO $\cdot$ Ebola $\cdot$ Responsibility $\cdot$ Legal personhood $\cdot$ PHEIC $\cdot$ International Organisations

\footnotetext{
M. Eccleston-Turner ( $₫)$

Keele University, Newcastle-under-Lyme, England, UK

e-mail: m.r.eccleston-turner@keele.ac.uk

Fondation Brocher, Geneva, Switzerland

S. McArdle

University of Lincoln, Lincoln, England, UK 


\section{Introduction}

The law of responsibility establishes consequences and redress for breaches of international law; it is a longstanding element of public international law. ${ }^{1}$ At its most basic, responsibility in international law ensures some form of culpability for an international wrongful act and gives rise to an obligation for the wrongdoer to provide redress. The key principles in the law of responsibility establish that responsibility will arise when an internationally wrongful act has been committed, which constitutes a breach of international law, and which is attributable to the international actor concerned. ${ }^{2}$ In this chapter we apply the principles of the law of responsibility to the 2014 West African Ebola epidemic, arguing that legal responsibility can be established at an international level on the part of the World Health Organisation (WHO) for their delayed action in respect of the West African Ebola response.

The West African Ebola epidemic began in Guinea during December $2013,{ }^{3}$ and the WHO was officially notified of the outbreak on the 23rd of March, 2014. ${ }^{4}$ The WHO did not declare the outbreak to be a 'Public Health Emergency of International Concern' ${ }^{5}$ (PHEIC) until August 8th that year. ${ }^{6}$ By this time there were 1779 confirmed and suspected cases of Ebola, nearly a thousand of which were confirmed or suspected to have resulted in death. ${ }^{7}$ This delay between the WHO being made aware of the epidemic and declaring it a PHEIC has been the subject of considerable criticism in the literature. ${ }^{8}$ Further criticism came via the Report of the Ebola Interim Assessment Panel commissioned by the WHO, which stated that 'significant and unjustifiable delays occurred in the declaration of a PHEIC by the WHO.' 9

The International Health Regulations (IHRs) empower the Director-General of the WHO to declare an event a PHEIC. ${ }^{10}$ The IHRs were passed by the World Health Assembly in 2005, as an update to the 1969 Regulations, and serve as the primary set of rules that govern state conduct in the build up to and during infectious disease outbreaks. The overarching goal of the Regulations is to prevent, detect and respond to the international spread of infectious diseases and other public health

\footnotetext{
${ }^{1}$ Grotius (2005), Ch XVII, para. 1 (vol II, 884); and see the Prolegomena, para. 8 (vol. 1, 86), in Pellet (2010), at p. 5.

${ }^{2}$ Articles 1 and 2 Articles on the Responsibility of States for Internationally Wrongful Acts; Articles 3 and 4 Articles on the Responsibility of International Organisations.

${ }^{3}$ Briand et al. (2014).

${ }^{4}$ The WHO Ebola Response Team (2014).

${ }^{5}$ The WHO has the power to declare a PHEIC via the WHO, International Health Regulations (2005).

${ }^{6}$ World Health Organisation (2015a).

${ }^{7}$ WHO (2016).

${ }^{8}$ Gostin and Friedman (2014), Gostin (2015), Siedner et al. (2015) and Kekulé (2015).

${ }^{9}$ World Health Organisation (2015b).

${ }^{10}$ Article 12, ibid.
} 
emergencies ${ }^{11}$ whilst at the same time attempting to prevent unnecessary restrictions being placed upon trade and travel to affected states. ${ }^{12}$ The Regulations define a PHEIC as an extraordinary event which is determined: (i) to constitute a public health risk to other States through the international spread of disease and (ii) to potentially require a coordinated international response. ${ }^{13}$

The ability to declare an event a Public Health Emergency of International Concern provides the WHO with significant power and influence over international health affairs. First, such a declaration directs international attention and resources to the public health emergency ${ }^{14}$; this is intended to ensure a fast, coordinated global response to the outbreak. There is, however, a second, negative, element to this influence with the potentia significant impact on travel and trade that a PHEIC can give rise to. ${ }^{15}$

As Adam Rainis Houston identifies in his chapter, the concept of a declaring a disease as a PHEIC on the basis of characteristics did not properly exist before the 2005 revisions to the International Health Regulations; rather, only specific diseases (cholera, plague and yellow fever, and smallpox) were considered notifiable under the 1969 IHR. ${ }^{16}$ Since 2005 the WHO's mechanisms for determining if an event constituted a PHEIC have been tested on a number of occasions, resulting in a declaration in 2009 for H1N1 pandemic influenza, in 2014 for Polio, in 2016 for Ebola, and in 2016 for Zika, 2018 for Ebola in the DRC and 2019 for Covid-19. Other events-MERS in 2013 and yellow fever in 2016-have been considered potential PHEICs, but have not resulted in declarations. The seemingly inconsistent approach the WHO takes to declaring, or not declaring, an event a PHEIC has resulted in some considerable criticism of the Organisation and its decision-making processes in this area. ${ }^{17}$ While the focus of this chapter is on the 2014 West African Ebola outbreak, as this is arguably the most controversial use of the WHO's PHEIC powers in the new millennium, it is important to note that our arguments in respect of Ebola are generalisable to other PHEICs. We return to this later in the chapter.

In the meantime, we present four claims: first, that the WHO is a distinct legal actor on the international stage capable of incurring responsibility for its actions; second, that the WHO does not merely have the power to declare a PHEIC, but also

\footnotetext{
${ }^{11}$ See 'Foreword' and Article 2 World Health Organisation, 'International Health Regulations' (2005).

${ }^{12}$ Article 12, ibid.

${ }^{13}$ Article 12, ibid.

${ }^{14}$ Lawrence Gostin \& Eric Friedman, (n 5).

${ }^{15}$ A PHEIC being declared empowers the WHO to make a number of recommendations regarding the movement of persons, baggage, cargo, containers, conveyances, goods and/or postal parcels to states involved in, or at risk from, the outbreak. These recommendations to states can include the closing of borders between states; requiring vaccinations within the state or to gain entry; implement quarantine for those suspected of being affected; isolation for those affected; and implement entry or exit screening on persons from affected regions, and are designed to minimise or control the public health threat. See: Reinalda and Verbeek (2011).

${ }^{16} \mathrm{P} .[-]$.

${ }^{17}$ Andrus et al. (2010), Gostin and Lucey (2015) and Lucey and Gostin (2016).
} 
has a legal obligation to do so and to do so in a timely manner; third, that the WHO failed to discharge this legal obligation in failing to declare the recent Ebola outbreak in West Africa a PHEIC in a timely manner; and fourth, that the failure to declare a PHEIC in a timely manner gives rise to legal responsibility at the international level for the consequences of the delay.

\section{The WHO, Accountability and the Need for Responsibility}

As we have noted elsewhere, the WHO is substantially lacking in appropriate accountability mechanisms, particularly in respect of the actions of the Organisation during a PHEIC. ${ }^{18}$ We have also suggested appropriate mechanisms by which the WHO could improve its accountability mechanisms. ${ }^{19}$ Accountability and responsibility are inextricably linked: while reform of the accountability system would be of great benefit to the WHO and the international system as a whole, this should be done in combination with development of the international law of responsibility to enable greater redress for wrongful acts when they occur. The law of responsibility enables legal action to be brought against a responsible actor at the international level. ${ }^{20}$ As Hafner stated, "accountability seems to reflect primarily the need to attribute certain activities under international law to such actors as a precondition for imposing on them responsibility under international law." 21

Responsibility in international law originally developed in the context of the traditional nature of international law being focused around bilateral state relations and the importance of state sovereignty. If an international legal obligation had been breached then this offended the wronged state's sovereign rights and, consequently, such state should have the ability to reinforce and uphold its rights. Consequently, the law of responsibility was the law of state responsibility. ${ }^{22}$ In spite of this early limitation, the ability to apply this law beyond the state was soon being called for. ${ }^{23}$ These calls largely arose in response to the growth of international organisations,

\footnotetext{
${ }^{18}$ Eccleston-Turner and McArdle (2017).

${ }^{19}$ ibid.

${ }^{20}$ See for example Articles 1 and 31 Articles on Responsibility of states for Internationally Wrongful Acts, with commentaries 2001, Yearbook of the International Law Commission 2001, 2001, vol. II, Part Two and Articles 3 and 31 Articles on the Responsibility of International Organisations, with Commentaries, 2011, Yearbook of the International Law Commission, 2011, vol. II, Part Two.

${ }^{21}$ Hafner (2003), at 237.

${ }^{22}$ Articles on the Responsibility of States for Internationally Wrongful Acts, General Assembly Resolution 56/83 of 12 December 2001; Report of the ILC, 53rd Session, ILC Yearbook 2001, Vol. II(2), 25.

${ }^{23}$ First Report by El Erian (1963) at p. 184; Report by Ago (1963) at p. 234; Exchange of Letters Constituting an Agreement relating to the Settlement of Claims filed against the United Nations in the Congo by Belgian nationals New York, 20 February 1965, No. 7780 (1965) Recueil des Traités p. 198; Kent (2005); The Secretary 'General, Investigation by the Office of Internal Oversight
} 
both in terms of number and powers. This eventually led in 2009 to the International Law Commission (ILC) developing the Articles on the Responsibility of International Organisations (ARIO). ${ }^{24}$ In spite of the established differences in nature and powers of states and international organisations, ${ }^{25}$ the ARIO largely mirror the ILC's earlier Articles on State Responsibility, ${ }^{26}$ which are well established within international law. While the principles may largely still be in their infancy in respect of international organisations, there exists a breadth of state-based practice to assist in the interpretation and application of such principles.

In order for the actions of the WHO to be addressed by the ARIO, and in order for the WHO's delay in declaring a PHEIC to be addressed by the law of responsibility, two factors must be established. First, the WHO must be accepted as a distinct legal actor at the international level. Second, the ability to declare a PHEIC in a timely fashion must be considered to not just be a power of the WHO, but a legal obligation as well. We argue below that these two factors can be established. From this it will be clear that there exists an international obligation on the part of an autonomous international actor, which was not upheld in this situation.

\section{The WHO as an Autonomous International Actor: A Capacity for Responsibility?}

The first thing that must be considered is the nature of the WHO as an autonomous subject of international law, as only subjects of international law are capable of possessing the sort of legal personality required in order to be subject to the law of responsibility. The broad concept of autonomy is a complex one. In existing in this distinct manner, it is only autonomous institutions with this separate will that are capable of incurring legal responsibility. ${ }^{27}$

While the overarching idea of autonomy can be a useful one, it is quite broad. A more concrete idea can be found in legal personality, which identifies subjects of international law capable of possessing rights, duties, powers and, crucially, obligations and liabilities of their own accord, and distinct from those of its Member States. ${ }^{28}$ This firmer legal concept can be aligned with the idea of identifying a separate will of an organisation; in addressing autonomy and the idea of a distinct

\footnotetext{
Services into Allegations of Sexual Exploitation and Abuse in the United Nations Organisation Mission in the Dem. Rep. Congo, U.N. Doc. A/59/661 (Jan. 5, 2005).

${ }^{24}$ Report of the ILC, 61st Session, 2009, A/64/10, 13-178.

${ }^{25}$ Reparation for injuries suffered in the service of the Nations, Advisory Opinion, [1949] ICJ Rep 174, ICGJ 232.

${ }^{26}$ Articles on the Responsibility of States for Internationally Wrongful Acts, General Assembly Resolution 56/83 of 12 December 2001; Report of the ILC, 53rd Session, ILC Yearbook 2001, Vol. II(2), 25.

${ }^{27}$ Klabbers (2011), at p. 122; Sari (2011).

${ }^{28}$ White (2005), at p. 31.
} 
will, many commentators focus on the presence (or absence) of legal personality. ${ }^{29}$ Personality is important not only in identifying a distinct identity on the part of the organisation, but it also in establishing whether an organisation has the capacity to incur responsibility as a distinct actor on the international stage. In spite of personality being slightly more concrete than the overarching idea of autonomy, there does not exist a clear definition of personality in international law. International law is largely state-centric, and states are presumed to have legal personality by their very nature; but the expansion of personality beyond the state has not led to a clear definition.

Institutions were first accepted as having the capacity for legal personality by the International Court of Justice in "Reparations" in relation to the United Nations in 1949:

In the opinion of the Court, the Organisation was intended to exercise and enjoy, and is in fact exercising and enjoying functions and rights which can only be explained on the basis of the possession of a large measure of international personality and the capacity to operate upon an international plane. ${ }^{30}$

In spite of this acceptance, identifying personality continues to be complex. The above statement, while utilised by many as a definition, has long been criticised, ${ }^{31}$ both in terms of its mention of a 'degree' of personality when such a concept is a discrete one, and also in terms of its circularity. This criticism has given rise to continued debate as to precisely how to establish personality. ${ }^{32}$ In spite of the criticism, an engagement with the concepts in the statement, while somewhat difficult, becomes almost inevitable. The important consideration begins with the intentions of member states, primarily those intentions explicitly mentioned but also, building from this, implicitly derived through the actions, powers and organs of the institution in an attempt to identify this broad notion of a 'distinct will'.

Ensuring the intentions of the member states may be a useful starting point, but this approach is limited when applied to multi-layered, multi-faceted supraorganisations such as the UN or the WHO; the intentions of the member states very often are not stated or are unclear. Indeed, the role, functions, and powers of such organisations are organic in nature: they grow, shift and develop over time without a conscious statement of the intentions of the member states that are enabling this growth and development. Many organisations now differ substantially in role, functions, and powers from those which were created in the post-war era, with much of this development having been unconscious and evolutionary as opposed to explicit member state reform. The consequence is that, to identify personality, intentions are inferred from considering aspects of the institution: such as a degree of permanency and distinct purposes and powers, the existence of organs within the institution with the

\footnotetext{
${ }^{29}$ White (2005), at p. 30.

${ }^{30}$ Reparations for injuries suffered in the service of the United Nations, Advisory Opinion ICJ Reports, 1949, p. 179.

${ }^{31}$ Brölmann (2007), at p. 78; White (2005), at p. 44.

${ }^{32}$ Seyersted (1964), Klabbers (1998), see in particular, 243-249; Klabbers and Wallendahl (2011).
} 
capacity for decision making, and the exercise of powers, without the prior approval of the member states. ${ }^{33}$

Determining the WHO's personality is slightly more complex than with some other institutions due to its existence as a specialised agency of the UN. ${ }^{34}$ As with most other international organisations, there is no definitive statement on personality in its founding documents, meaning there was no distinct conferral of personality on the WHO from the Member States at the time of its creation. The Reparations statement then directs us to consider a more implicit conferral of personality from the Member States; when considering the powers and capacities given to an institution, personality can be identified.

The Constitution of the WHO considers its "legal capacity, privileges and immunities", which are to be determined by the WHO in "consultation" with the SecretaryGeneral of the United Nations and concluded between the Members of the WHO. ${ }^{35}$ While this statement does not state much about personality and capacity, it can be interpreted to show the WHO to have "legal capacity, privileges and immunities", which could go some way towards establishing personality. It is significant that such capacity is to be "determined" by the organisation itself. ${ }^{36}$ This is an important element. The power to develop its own capacity, even to a small degree, shows a significant element of 'separate will' from its members on the part of the institution.

Moreover, it is interesting that some mention of personality is made in the Convention on the Privileges and Immunities of the Specialised Agencies, concluded by the UN General Assembly. ${ }^{37}$ This Convention, which does apply to the WHO, makes explicit reference to the institution possessing 'juridical personality', and defines this as the capacity "(a) to contract, (b) to acquire and dispose of immovable and movable property, [and] (c) to institute legal proceedings". ${ }^{38}$ In explicitly recognising an aspect of legal personality and in attempting to delimit it in a specific way, the Convention recognises that the organisation has the ability to act in a manner that is distinct from its Member States. There is an identification of the WHO as being separate from its Members, not just broadly in terms of its actions but in far more legal terms.

The considerable expansion of the role, functions, and powers of the WHO since they were first articulated in 1946 only strengthens the case for establishing legal personality and determining the $\mathrm{WHO}$ as an autonomous institution. The Member States have allowed the role, functions and powers of the WHO to move its personality beyond that which was initially envisaged in the founding of the organisation. In the

\footnotetext{
${ }^{33}$ White (2005), at pp. 30-32.

${ }^{34}$ Article 69, Constitution of the World Health Organisation.

${ }^{35}$ Article 68, Constitution of the World Health Organisation.

36 ibid.

${ }^{37}$ Adopted by the First World Health Assembly on 17 July 1948 (Off. Rec. Wld Hlth Org., 13, 97, 332).

${ }^{38}$ Adopted by the First World Health Assembly on 17 July 1948 (Off. Rec. Wld Hlth Org., 13, 97, 332), Section 3.
} 
words of the ICJ opinion in Reparations this can only be explained by the possession of international personality, and a capacity to operate upon an international plane. ${ }^{39}$

While some progress on this argument can be made in relation to the initial idea of will and powers, further support can be found in the institutional structure of the WHO: it possesses its own organs. Under its auspices exist the World Health Assembly, the Executive Board, and the Secretariat, each of which has a number of distinct powers to act on behalf of the WHO. The Assembly, for example, determines policies and adopts regulations, which can be seen as akin to a legislative process. It is also able to adopt conventions with respect to the objectives of the WHO. The Executive Board exists as an executive organ of the Health Assembly, although it must be noted that it has some degree of independence from the Assembly, and thereby from the Member States that make up the Assembly. For instance, while membership of the Board is elected by the Assembly, the Board does not need to reflect the national membership of the Assembly, ${ }^{40}$ implying that the Board members are acting in a manner that is institutionally distinct from the Assembly and the Member States. Moreover, the Board elects its own Chair and sets its own rules and procedures, ${ }^{41}$ addresses any questions within its competence, ${ }^{42}$ sets the agenda for the Assembly, ${ }^{43}$ and proposes the general programme of work for the Assembly to vote upon. ${ }^{44}$ Each of these powers and duties of the Board implies that it is distinct from the Assembly and the decision-making powers of the Member States that make up the Assembly. Most notably in this regard however, is the fact that the Board has the power to take emergency measures within the functions and financial resources of the Organisation to deal with events requiring immediate action. In particular it may authorise the Director-General to take the necessary steps to combat epidemics, to participate in the organisation of health relief to victims of a calamity and to undertake studies and research the urgency of which has been drawn to the attention of the Board by any Member or by the Director-General. ${ }^{45}$

While the Board typically exists to work in harmony with the Assembly, and the Member States that comprise it, it is clear that it has some degree of independence, particularly when responding to epidemics and calamities such as Ebola. The existence of distinct organs in this fashion begins to give further credence to the existence of personality on the part of the WHO. While the existence of organs in themselves may not be a determining factor, their distinct identity as providing much more than a simple discussion forum for Member States can contribute towards the argument of an institution possessing personality. When considering the WHO's organs, they exist as part of the institution and, most particularly, do so during epidemics the

\footnotetext{
${ }^{39}$ Reparations for injuries suffered in the service of the United Nations, Advisory Opinion ICJ Reports, 1949, p. 179.

${ }^{40}$ Article 25, Constitution of the World Health Organisation.

${ }^{41}$ Article 27, Constitution of the World Health Organisation.

${ }^{42}$ Article 28(h), Constitution of the World Health Organisation.

${ }^{43}$ Article 28(f), Constitution of the World Health Organisation.

${ }^{44}$ Article 28(g), Constitution of the World Health Organisation.

${ }^{45}$ Article 28(i), Constitution of the World Health Organisation.
} 
management and prevention of which is one of the key functions of the Organisation itself. $^{46}$

When considering further powers of the WHO, its ability to accede to international treaties also gives particular credence to an existence of legal personality. It is particularly telling that the WHO acceded to the Vienna Convention on the Law of Treaties in spite of the existing accession of many of its Member States. ${ }^{47}$ The report of the Secretariat of the Executive Board on the Participation by the WHO to the Vienna Convention is interesting in this respect. ${ }^{48}$ In this Report, drafted by the Secretariat, the Executive Board of the WHO advises the WHA to authorise the Director-General of the WHO to sign the Convention. This Report clearly discusses the WHO as an actor distinct from its Member States. Indeed, many Member States of the WHA were already signatories to the Convention by this stage, the implication being that the membership of its Member States was insufficient to bind the WHO to the Convention, and accession by the WHO as a distinct legal actor was required. This led to the WHO signing the Convention in 1987 and giving formal confirmation of its intention to be bound, without reservations, in $2000 .^{49}$

All of these points show that the WHO has the capacity to act in a distinct fashion that is beyond the sum of its parts; it is more than simply a collective of its Member States. In existing in this distinct manner and having certain rights, powers and obligations as this distinct actor, it clearly possesses legal personality. The WHO's legal personality gives it both the capacity to act in certain areas within its remit, but also makes it 'subject to international law', giving rise to the need to provide redress for any issues arising from its actions, or omissions, in the areas within its competence. It has the capacity for legal responsibility arising from its powers. In order to consider any possibility of legal responsibility, however, the existence of obligations over and above powers to act must first of all be found.

The identification of obligations on the part of institutions, rather than simply powers to act, has been a difficult one to determine in relation to international organisations. The traditional state-centric international system recognises two main sources of international law: customary principles, and international treaties. How these sources of international law apply to institutions, such as the WHO, has long been questioned. While the ICJ has often stated that obligations exist on the part of institutions, ${ }^{50}$ a clear identification of such obligations, or even the source of such obligation, is rare.

We argue that such a legal obligation does exist on the part of the WHO in the requirement to declare an extraordinary event a PHEIC in a timely manner. While this is not stated in explicit terms, we draw upon a number of sources below in more detail to argue this. It must first of all be noted that when examining the IHR and the obligation to declare a PHEIC, that the language used is not that of the discretionary

\footnotetext{
${ }^{46}$ Article 2(g), Constitution of the World Health Organisation.

${ }^{47}$ United Nations, Vienna Convention on the Law of Treaties (1969).

${ }^{48}$ World Health Organisation (1999).

${ }^{49}$ United Nations (2016a).

${ }^{50}$ ICJ Reports 1980, pp. 89-90, para. 37.
} 
'may', but of the obligatory 'shall'. As noted above, a PHEIC can only be declared by the Director-General, ${ }^{51}$ on the advice of an Emergency Committee, which is convened by the Director-General. ${ }^{52}$ The decision to declare (or not to declare, as the case may be) an event a PHEIC is one that has significant repercussions for affected states. While the International Health Regulations provides the DirectorGeneral with the power to declare an extraordinary event a PHEIC, we argue that the Director-General actually has a legal obligation to declare an event a PHEIC and to do so in a timely manner. The first element of this obligation to declare may have been eventually fulfilled but (as we will argue in a moment), the failure to declare the 2014 West African Ebola outbreak a PHEIC in a timely fashion was not, and therefore constitutes an internationally wrongful act, for which responsibility ought to arise on the part of the Organisation.

The finalised articles on the Responsibility of International Organisations establish that in order for responsibility to be established, an internationally wrongful act must be identified. ${ }^{53}$ There are two key elements that constitute an internationally wrongful act: a breach of an international obligation, and attribution of that breach to the responsible international actor. ${ }^{54}$ Could the delay in the declaration of a PHEIC by the Director-General, on behalf of the WHO, be a breach of an international legal obligation that can be attributed to the institution, resulting in legal responsibility? Arguably, it could.

In identifying a breach of international law, the commentaries to the ILC's articles provide some guidance as to what will be sufficient; they consider that any source of international law applicable to the organisation will suffice. ${ }^{55}$ The ILC elaborates further with reference to the International Court of Justice (ICJ) advisory opinion on the Interpretation of the Agreement of 25 March 1951 between the WHO and Egypt, stating that international organisations are bound by any obligations incumbent upon them under general rules of international law, under their constitutions or under international agreements to which they are parties. ${ }^{56}$

The legal obligation to declare a PHEIC is not explicitly identified as an obligation in and of itself within the relevant core documents of the WHO. Rather, numerous obligations are identified within the Constitution of the World Health Organisation, in particular Articles 2(v), (a) and (g) of the Functions, and an external agreement with the African Congress, which when taken together would create the legal obligation pursuant upon the WHO to declare the West African Ebola outbreak PHEIC and, secondly, to do so in a timely fashion. We explore these obligations below.

\footnotetext{
${ }^{51}$ Article 12, International Health Regulations.

${ }^{52}$ Article 12(4), International Health Regulations.

${ }^{53}$ Articles 3 and 4, Articles of the Responsibility of International Organisations.

${ }^{54}$ Article 4, Articles of the Responsibility of International Organisations.

${ }^{55}$ Commentary to Article 4, para. 2, p. 14.

${ }^{56}$ ICJ Reports 1980, pp. 89-90, para. 37.
} 


\section{The Timely Declaration of a PHEIC as a Legal Obligation}

The Constitution of the World Health Organisation is the founding document of the Organisation and was adopted by the International Health Conference, a meeting of the Economic and Social Council of the United Nations, in $1946 .{ }^{57}$ Despite the fact that it has been amended four times, ${ }^{58}$ the Objective and Functions of the World Health Organisation remain largely unchanged from the original text that was approved in 1946. The simple, if somewhat lofty, objective of the World Health Organisation is 'the attainment by all peoples of the highest possible level of health.' ${ }^{59}$ The Constitution of the WHO also outlines the manner in which the WHO intends to meet this objective and ensure all peoples attain the highest possible level of health via the 'Functions' provided at Article 2 of the Constitution. Within the Functions of the Constitution there is no explicit obligation to make a timely declaration of a PHEIC: indeed, there is no reference to the notion of a PHEIC in the Constitution at all. However, there are obligations pursuant upon the WHO set out at the Functions of the Constitution that give rise to an obligation to make a timely declaration of a PHEIC.

The first relevant Function that gives rise to an obligation on the WHO to make a timely declaration of a PHEIC is contained within Article 2 of the WHO Constitution, and requires the WHO 'generally to take all necessary action to attain the objective of the Organisation' ${ }^{60}$ Clearly a prompt and effective global response to an epidemic, a response which is instigated by the declaration of a PHEIC by the WHO, is needed to ensure all affected, or at risk, persons can attain the highest possible level of health. While this is a broad Function of the Organisation, and in and of itself it cannot be said to confer upon the WHO specific and particular obligations in respect of declaring a PHEIC in a timely manner, when taken in combination with the two further Functions outlined below, a compelling case can be made that there $i s$ an obligation binding upon the WHO to declare a PHEIC, and to do so in a timely manner. The first additional relevant function outlined at 2(a) of the Constitution outlines that the WHO is 'to act as the directing and coordinating authority on international health work' ${ }^{61}$ The WHO's role as directing and coordinating authority during a major outbreak such as Ebola is typically triggered by a declaration of a PHEIC by the WHO. Article 13 of the IHR states that a PHEIC Declaration being made triggers the following response from WHO:

\footnotetext{
${ }^{57}$ For an interesting historical perspective on the development of the Constitution see: Grad (2002).

${ }^{58}$ World Health Assembly, Resolution WHA26.37 'Amendments to articles 34 and 55 of the Constitution' (1973), World Health Assembly, WHA29.38 'Amendments to articles 24 and 25 of the Constitution' (1976); World Health Assembly, WHA39.6 'Amendments to articles 24 and 25 of the Constitution' (1986); World Health Assembly, WHA51.23 'Amendments to articles 24 and 25 of the Constitution' (1998).

${ }^{59}$ Article 1, International Health Regulations.

${ }^{60}$ Article 2(v), International Health Regulations.

${ }^{61}$ Article 2(a), International Health Regulations.
} 
At the request of a State Party, WHO shall collaborate in the response to public health risks and other events by providing technical guidance and assistance and by assessing the effectiveness of the control measures in place, including the mobilisation[sic] of international teams of experts for on-site assistance, when necessary. ${ }^{62}$

Further, if the WHO considers that a PHEIC is occurring it can assess the severity of the event, the adequacy of support, and offer additional assistance: Such collaboration may include the offer to mobilise[sic] international assistance in order to support the national authorities in conducting and coordinating on-site assessments. ${ }^{63}$

This process of having the WHO coordinate and direct the response to an outbreak is crucial in ensuring an effective response from the affected states and the wider international community. A PHEIC declaration triggers the mechanisms of the WHO into action, and also directs international attention and resources to the outbreak. A consequence of this is that any PHEIC declaration must be done in a timely fashion. A PHEIC works to direct and coordinate action in response to an outbreak, and so a failure to act in a timely fashion will affect the ability to respond to a crisis. This can be seen with comments by the Report of the Ebola Interim Assessment Panel that during the Ebola outbreak the 'WHO not only coordinates the health cluster, but is also responsible for the coordination of specific technical activities such as surveillance. In the Ebola crisis, WHO should have had a key role to play in coordination, but it took a long time to get this started. ${ }^{64}$

The second relevant function of the WHO that could give rise to there being an obligation to declare a PHEIC in a timely fashion is 'to stimulate and advance work to eradicate epidemic, endemic and other diseases ${ }^{65}$ Clearly this cannot be adequately achieved without the timely declaration of a PHEIC by the Director-General. As noted above, a PHEIC declaration not only triggers the mechanisms of the WHO, but also directs international attention and resources to the outbreak-resources that are key to controlling or eradicating disease.

These Functions, which are binding upon the WHO through its Constitution, give rise to international obligations, which in turn are binding upon the WHO itself. When these obligations are taken together, the natural consequence is an obligation to declare a PHEIC when the appropriate circumstances arise, and to make said declaration in a timely fashion. The WHO is the coordinating authority on global health and, from its Constitution, possesses obligations to work towards the eradication of disease and to pursue the highest possible level of health. These obligations cannot be satisfied without the timely declaration of a PHEIC.

Hence, it would appear that the internal obligations stemming from the Constitution of the WHO are sufficient to create a legal obligation pursuant upon the WHO to declare a PHEIC in a timely fashion when it appears right to do so. Moreover, this legal obligation stemming from the Constitution is not limited to the 2014 West African Ebola outbreak, but any other extraordinary event that meets the criteria to be

\footnotetext{
${ }^{62}$ Article 13(3), International Health Regulations.

${ }^{63}$ Article 13(4), International Health Regulations.

${ }^{64}$ World Health Organisation, (n 9).

${ }^{65}$ Article 2(g), International Health Regulations.
} 
declared a public health emergency of international concern. This obligation may be bolstered by external agreements to which the WHO is a party as part of its external relations.

In the case of the 2014 West African Ebola outbreak, in addition to the internal obligation stemming from the Constitution, there was an external obligation on the WHO to make a timely declaration of a PHEIC. This is derivable from the membership of the African Union of Sierra Leone, Guinea, and Liberia, the states that were most seriously impacted by the outbreak, with which the WHO signed an agreement in 2012. The WHO's agreement with the Commission of the African Union includes an obligation "to contain [...] crises and outbreaks of disease, and impart [...] knowledge and skills". 66 The declaration of a PHEIC is envisaged to address "a public health risk to other States through the international spread of disease" and, consequently, an obligation to contain crises and outbreaks of disease ought naturally to give rise to an obligation to utilise any legal tools that may assist with this. A PHEIC declaration is clearly a central tool through which this obligation is fulfilled. Not only is there a general obligation to declare a PHEIC when appropriate in a timely fashion, but the WHO-AU Agreement created an obligation upon the WHO to do as much as possible to contain disease outbreaks in African Union Member States which would clearly include declaring a PHEIC where appropriate. This is an obligation that was clearly not fulfilled in respect of the 2014 West African Ebola outbreak.

The central aspect of a PHEIC is the actions that may arise from it. A PHEIC declaration not only triggers the mechanisms of the WHO outlined above, but also directs international attention and resources to the outbreak-resources that are key to the control or eradication of disease. In the case of the 2014 Ebola epidemic, the PHEIC declaration did not occur until August 8th, over six weeks after Médecins Sans Frontières had warned that Ebola was 'out of control', and had called for a 'massive deployment of resources'. ${ }^{67}$ Senior staff at the WHO had also raised the prospect of declaring a PHEIC, but it was resisted. ${ }^{68}$ As Gostin and Friedman noted, international donations, technical assistance and military assistance finally began to flow to the region only after the PHEIC was declared. ${ }^{69}$ This was despite the fact that the WHO had briefed the international community on the seriousness of the outbreak from 8th April, with increasing emphasis being placed on the severity of the outbreak up to the point a PHEIC was declared. ${ }^{70}$ It is clear that a PHEIC declaration was appropriate in this instance. As such, the appropriate and timely declaration of a PHEIC is central in ensuring the obligations for preventing crises and spread of disease mentioned both generally within the WHO Constitution, and specifically in

\footnotetext{
${ }^{66}$ World Health Assembly, "Agreements with intergovernmental organisations: agreement between the Commissions of the African Union and the World Health Organisation" (2012) A65/42.

${ }^{67}$ Médecins Sans Frontières (2015).

${ }^{68}$ Cheng and Satter (2015).

${ }^{69}$ Lawrence Gostin \& Eric Friedman, (n 5).

${ }^{70}$ World Health Organisation (2015c) at 'Chapter 7-Key events in the WHO response to the Ebola outbreak'.
} 
the particular agreement between the WHO and the AU. The failure to declare a PHEIC in a timely fashion is capable, therefore, of giving rise to responsibility and the specific legal principles on this will now be considered.

\section{Determining Responsibility for the Delay Responding to Ebola}

While the WHO did declare a PHEIC in relation to the West African Ebola outbreak, thereby satisfying the first stage of their legal obligation, that declaration was not timely, and therefore did not satisfy the second stage of the obligation. Timely in this context should be flexible in its application to individual circumstances-a set period of time cannot be attached to it, but rather reasonableness with regard to all the circumstances should be the guiding principle. The period between the criteria for declaring a PHEIC having been met and a declaration being made ought to be as short as possible and with no unjustifiable delay. Ultimately, questions of timeliness will be resolved by determining if the Director-General could have acted more quickly in declaring a PHEIC once the criteria for doing so had been satisfied. In relation to Ebola the declaration of a PHEIC was not timely, inasmuch as that there were no justifiable reasons for this delay.

The WHO was originally notified of the outbreak on 23rd March 2014 but, as we have seen, it was not until 8th August that a PHEIC was declared. By the time a PHEIC was declared there were 1779 confirmed and suspected cases of Ebola, nearly a thousand of which were confirmed or suspected to have resulted in death. ${ }^{71}$ The Ebola Interim Assessment Panel, set up by the WHO itself, stated that there were "significant and unjustifiable delays" in the declaration of a PHEIC by the WHO. ${ }^{72}$ Furthermore, when examining the communications about the Ebola situation, it is clear that in the time between the WHO being made aware of the Ebola crisis and its decision to declare a PHEIC, numerous individuals and bodies with expertise in this area were arguing that the situation was a severe one that required further action and attention from the WHO. Internal WHO communications show clear concerns about the severity of the outbreak and the lack of action on the part of the WHO, including the virus spread being worse than the data implied and continued pleas for assistance from staff on the ground not being answered, as well as refusals to consider convening an Emergency Committee, which would begin the process of declaring a PHEIC. ${ }^{73}$ These communications show that there was a two-month delay from the WHO having become aware of the severity of the outbreak in West Africa to

\footnotetext{
${ }^{71}$ WHO (2016).

${ }^{72}$ World Health Organisation, (n 9).

${ }^{73}$ Associated Press, "Emails Show WHO Resisted Declaring Ebola an Emergency," NBC News (NBC News), March 20, 2015, Accessed May 15, 2017. http://www.nbcnews.com/storyline/ebolavirus-outbreak/emails-un-health-agency-resisted-declaring-ebola-emergency-n326956.
} 
an Emergency Committee being convened. ${ }^{74}$ Taking two months to begin to move towards the process of declaring a PHEIC is not plausibly timely, especially when taken together with the knowledge of how severe the outbreak was becoming.

In order for responsibility to be established, any breach of international law must be attributed to the international actor concerned. It is the requirement of attribution that is often problematic when considering international organisations. The transparent nature of institutions means that it is often difficult to determine with certainty the action as being that of the institution. Action is often carried out by Member States on behalf of the institution and determining that an action is that of the institution as opposed to the state is complex. The declaration of a PHEIC is, arguably, an exception to this difficulty.

The basic rule of attribution in the ARIO is that all actions of an organ or agent of the institution are attributed to that institution. ${ }^{75} \mathrm{~A}$ substantial critique of the ARIO has been that this is limited in its application as institutions often depend upon their member states to carry out their actions and obligations. When considering the actions of the WHO in these circumstances, however, it is clear that it is the 'pure' institutional organs and agents that are being considered. The decision to declare a PHEIC is one that lies with the Director-General of the WHO. As the DirectorGeneral is clearly an agent of the WHO and not acting on behalf of a Member State of the organisation, any failure to declare a PHEIC in a timely fashion will be attributed to the WHO through agency. With the elements of breach and attribution being satisfied in respect of the failure to declare the 2014 West African Ebola outbreak a PHEIC in a timely fashion, there exists an internationally wrongful act, attributable to the WHO through an agent of the organisation, for which responsibility on the international stage can be established.

\section{The Practical Limitations of Responsibility}

In spite of the clear ability to determine responsibility in this regard, it should be noted that enforcing this is far from straightforward. There are numerous practical limitations to finding and giving effect to any determination of responsibility in relation to an international organisation like the WHO. Not only is there a question about a lack of judicial fora before which cases on breach of international law by international organisations could be brought, but there is also the question of practical consequences arising from actions before such courts, if one with appropriate jurisdiction could be identified. A determination of responsibility gives rise to an obligation to make reparation. ${ }^{76}$ The extent to which this is possible in the present case, both in terms of enforcement, and of where any money would be drawn from in order to make such reparation, is highly questionable.

\footnotetext{
${ }^{74}$ ibid.

${ }^{75}$ Article 6 Articles of the Responsibility of International Organisations.

${ }^{76}$ Article 31, ARIO.
} 
Regarding enforcement, there does not exist an identifiable court before which the WHO could be taken by a state, or indeed an individual or institution affected by the WHO's omissions in the present case, to enforce the determination of responsibility. This is one of the fundamental weaknesses of responsibility in relation to international organisations; there are few, if any, possibilities in terms of judicial fora. When considering the case law that has discussed the principles contained in the ARIO, it is notable that all of them return to the responsibility of a state, after engaging with the ARIO principles in respect of the relevant institutions in order to 'discount' the institution concerned, return to the responsibility of the states concerned. ${ }^{77}$ It is difficult to conceive of a case where the responsibility of an institution could be explicitly determined and later enforced. This is all before considering the difficult question of immunity, which is a principle that has continued to block numerous cases considering the responsibility of the United Nations. ${ }^{78}$

While there are questions about the existence and nature of institutions' immunity, including discussions about whether they are absolute or limited, most consider the UN to possess an absolute immunity from prosecution in line with Article 105(1) of the UN Charter, together with section two of the Convention on Privileges and Immunities of the United Nations (1946), which states:

The United Nations, its property and assets wherever located and by whomsoever held, shall enjoy immunity from every form of legal process except insofar as in any particular case it has expressly waived its immunity. ${ }^{79}$

While it was established early on that such prosecution was in relation to national law and did not preclude international responsibility, ${ }^{80}$ the lack of an international judicial system has necessarily meant that these questions arise in national courts. With the questions arising in relation to national law, immunity arises time and again. Furthermore, the WHO constitution states that

[t]he Organisation shall enjoy in the territory of each Member such privileges and immunities as may be necessary for the fulfillment of its objective and for the exercise of its functions. ${ }^{81}$

\footnotetext{
${ }^{77}$ Behrami and Behrami v France and Saramati v France, Germany and Norway App no 71412/01 and 78166/01 (ECtHR 2 May 2007); R (on the application of Al-Jedda) v Secretary of State for Defence, [2008] 1 AC 332; Case of Al Jedda v the United Kingdom App no. 27021/08 (ECtHR, 7 July 2011); Netherlands (Ministry of Defence and Ministry of Foreign Affairs) v Nuhanović, Final appeal judgment, ECLI/NL/HR/2013/BZ9225, ILDC 2061 (NL 2013), 12/03324, Supreme Court (6 Sept 2013); Claimant 1 et al. and the Mothers of Srebrenica v the State of the Netherlands and the United Nations Case Number C/09/295247/ HA ZA 07-2973, Judgment of The Hague District Court (16 July 2014).

${ }^{78}$ See, for example, Netherlands (Ministry of Defence and Ministry of Foreign Affairs) v Nuhanović, Final appeal judgment, ECLI/NL/HR/2013/BZ9225, ILDC 2061 (NL 2013), 12/03324, Supreme Court (6 Sept 2013); Claimant 1 et al. and the Mothers of Srebrenica v the State of the Netherlands and the United Nations Case Number C/09/295247/ HA ZA 07-2973, Judgment of The Hague District Court (16 July 2014).

${ }^{79}$ Article 2, United Nations, 'Convention on Privileges and Immunities of the United Nations' (1946).

${ }^{80}$ Difference Relating to Immunity from Legal Process of a Special Rapporteur of the Commission on Human Rights, Advisory Opinion [1999] ICJ Reports p. 62 at p. 88.

${ }^{81}$ Article 67(a), Constitution of the World Health Organisation.
} 
The UN General Assembly concluded the Convention on the Privileges and Immunities of the Specialised Agencies that explicitly included the WHO within its remit. ${ }^{82}$ Although the International Court of Justice is seemingly given some remit for action by the Constitution of the WHO, and also specifically within the Convention on Privileges and Immunities, this is substantially limited when read together with provisions of the Statute of the ICJ. Only states are able to be parties to adversarial proceedings before that Court. ${ }^{83}$ Any proceedings involving international organisations can only be heard by the Court in the remit of an advisory opinion, in respect of interpreting international law, not enforcing it. Overall, it appears that the ability to establish responsibility judicially is highly limited; the remit of the ICJ is restricted and all attempts to bring cases in national courts have resulted in immunity preventing any action proceeding against the international organisation. While there have been some limited examples of litigants looking beyond immunity where not to do so would lead to a 'denial of justice', ${ }^{84}$ this appears to be a highly limited approach largely addressing private law cases; cases beyond this in the sphere of public law have seen continual deference to immunity, in particular in relation to the United Nations. ${ }^{85}$ In the present case, the $\mathrm{WHO}$ is privilege to the same immunity and protection from legal action as the UN.

The funding of reparation is a more complex issue that returns, again, to the difficult nature of the identity of an international organisation. Institutions are dependent for their budget upon their member states, and a call for reparation raises a number of difficulties. It must be considered whether the institution would pay for such reparations out of its general budget, or whether it would be feasible for it to call upon member states to contribute to a special fund in order to fulfill its reparation obligations. The difficulties surrounding this can be seen with the issues arising from the outbreak of cholera in Haiti, and the attempt by the UN to set up a compensation fund in response to the outbreak ${ }^{86}$ : there continues to be uncertainty surrounding how this fund will be paid for. The UN has sought to address two main parts within this fund, one aspect being compensation for the victims and another being about eradication and prevention. There is a target for $\$ 200$ million for each of these parts.$^{87}$ However, it was initially unclear whether this should be funded from the general budget or from member state contributions. The approach eventually taken by the UN was to rely upon voluntary donations from member states. The consequence of this was that the

\footnotetext{
${ }^{82}$ Adopted by the First World Health Assembly on 17 July 1948 (Off. Rec. Wld Hlth Org., 13, 97, 332), Section 1(ii)(g).

${ }^{83}$ Article 34, United Nations, Statute of the International Court of Justice (1946).

${ }^{84}$ Application no. 26083/94, judgment of February 18, 1999 and Application no. 28934/95, Judgment of February 18, 1999.

${ }^{85}$ See, for example, Claimant 1 et al. and the Mothers of Srebrenica $v$ the State of the Netherlands and the United Nations Case Number C/09/295247/HA ZA 07-2973, Judgement of The Hague District Court (16 July 2014).

${ }^{86}$ United Nations (2016b).

${ }^{87}$ Gladstone (2017).
} 
fund never reached anywhere near $\$ 400$ million, and is currently at risk of running out completely. ${ }^{88}$

While it is important to ensure that the WHO follows its international obligations, it is questionable whether the imposition of legal responsibility, without immunity, would be effective in encouraging the WHO to engage in its role at the global level. If there arises a concern that its actions may result in determinations of responsibility, this may result in a more cautious approach by the WHO out of fear of liability being imposed through the law of responsibility. This may end up amounting to a disincentive on the part of the institution to act and develop. Even where an institution has developed a significant amount of autonomy, it remains dependent upon its Member States for expansion and development. If the consequence of developing an institution has been that Member States have been subjected to greater requirements for payment and effective obligations for reparations then this will only discourage the development here. There are huge potential benefits in the development of institutional frameworks and the ability that they have to address global issues, such as that of global health and, in this circumstance, epidemic and pandemic emergencies. It has to be asked whether a framework that may prove a disincentive on the part of states to act and enable global action is really the best approach here. Not only did the practical limitations to imposing liability on the WHO for the mismanagement of the PHEIC declaration during the West African Ebola outbreak serve to shut down any discussion of legal restitution from the WHO, but an opportunity to acknowledge the situation and make a step towards remedying it was lost.

\section{Conclusion}

The WHO has developed significantly since its inception in 1948. Its role and powers are far beyond what was originally envisaged. As the Organisation has evolved it has become increasingly distinct from its Member States, meaning that it now possesses a substantial degree of autonomy to act in an independent manner. Furthermore, the WHO has developed to face a number of obligations, as well as powers. However, this development has not been accompanied with any development of the WHO's internal accountability mechanisms, ${ }^{89}$ nor any meaningful engagement with external accountability and responsibility mechanisms. Since the 2005 revisions to the International Health Regulations, the manner in which the WHO has responded to a number of PHEICs, and potential PHEICs, has been subject to considerable criticism from member states and the academic literature. ${ }^{90}$ It is our contention that on at least one occasion the WHO, in responding to an extraordinary event that likely constitutes a PHEIC, has breached its legal obligations to declare such an event a PHEIC in a

\footnotetext{
${ }^{88}$ See: United Nations (2017).

${ }^{89}$ Eccleston-Turner and McArdle (2017).

${ }^{90}$ see (n 8).
} 
timely manner. This has been demonstrated most clearly with the WHO's delayed response to the Ebola outbreak in West Africa during the 2014 outbreak.

The argument we have presented in respect of the timely declaration of a PHEIC being a legal obligation of the WHO is not limited to Ebola. It applies equally to any other extraordinary event where the criteria for declaring a PHEIC have been met. This area becomes further complicated when we consider not only the timely declaration of a PHEIC as being an international legal obligation for which responsibility can be attributed to the WHO, but also the appropriate, timely downgrading of a PHEIC's status once the extraordinary event no longer meets the criteria to be considered a PHEIC. This again, is a decision that is delegated to the Director-General via the IHR, and one that has been subject to criticism for its usage. ${ }^{91}$ It is arguable that not only is the timely declaration of a PHEIC a legal obligation binding upon the WHO, but also that the timely and appropriate downgrading of a PHEIC amounts to a legal obligation binding upon the WHO (though the full development of that point is beyond the scope of this chapter).

In spite of the ability to make a legal determination of responsibility, this is highly unlikely to result in any sort of legal consequences. There is a substantial number of practical barriers that stand in the way of determining legal responsibility of an international organisation, from lack of judicial fora, to the principle of immunity and the difficult question of how to fund claims for reparation. A legal determination of responsibility in a judicial setting remains highly unlikely. Therefore, a productive move forward would be a clear and unequivocal acknowledgement of wrongdoing on the part of WHO when mistakes are made and the further development of accountability mechanisms. While this is highly limited, and the examples that do exist of institutions acknowledging wrongdoing have a number of substantial flaws, ${ }^{92}$ the possibility exists for institutions such as the WHO to develop internal mechanisms that work and allow some redress. Overall this will only improve the WHO's position in the global community and its work with its member states to develop better responses to disease outbreaks.

\section{References}

Ago R (1963) Chairman of the Sub Committee on State Responsibility, 16 January 1963, Document A/CN.4/152, in Yearbook of the International Law Commission 1963, vol 2, p 227 UN Doc/A/CN.4/SER.A/1963/Add. 1

Andrus JK et al (2010) Global health security and the International Health Regulations. BMC Public Health 10(1):S2

Briand S et al (2014) The international Ebola emergency. New Engl J Med 371:1180

Brölmann C (2007) The institutional veil in public international law: international organisations and the law of treaties. Hart, Oxford

\footnotetext{
${ }^{91}$ Most notably the 2014 Yellow Fever PHEIC in which the WHO faced considerable criticism for its early downgrading of Yellow Fever from a PHEIC.

${ }^{92}$ See above discussion on the UN, Cholera and Haiti at $\mathrm{p}[\ldots]$.
} 
Cheng M, Satter R (2015) Emails: UN Health Agency resisted declaring ebola emergency. Associated Press. http://bigstory.ap.org/article/ea7199795faa48989449131404b7043e/emailsun-health-agency-resisted-declaring-ebola-emergency. Accessed 21 Oct 2015

Eccleston-Turner M, McArdle S (2017) Accountability, international law, and the World Health Organisation: a need for reform? Global Health Gov XI(1):27-40

El Erian A (1963) Special Rapporteur, relations between states and inter governmental organisations, Document A/CN.4/161 and Add. 1, contained in ILC yearbook, vol II, A/CN.4/SER.A/1963/ADD.1, p 159

Gladstone (2017) After bringing cholera to Haiti, U.N. can't raise money to fight it. New York Times, New York, 19 Mar 2017. Available at: https://www.nytimes.com/2017/03/19/world/americas/ cholera-haiti-united-nations.html

Gostin L (2015) The future of the World Health Organisation: lessons learned from Ebola. Milbank Q 93:475

Gostin L, Friedman E (2014) Ebola: a crisis in global health leadership. Lancet 384:1323

Gostin L, Lucey D (2015) Middle east respiratory syndrome: a global health challenge. JAMA 314(8):771-772

Grad F (2002) The preamble of the constitution of the World Health Organisation. Bull World Health Org 981

Grotius H (2005) The rights of war and peace. In: Tuck R, Barbeyrac J (eds) 1625. Liberty Fund, Indianapolis

Hafner G (2003) Accountability of international organisations. In: Proceedings of the annual meeting (American Society of International Law), vol 97, pp 236-240

Kekulé AS (2015) Learning from Ebola virus: how to prevent future epidemics. Viruses 7:3789

Kent VL (2005) Peacekeepers as perpetrators of abuse. examining the UN's plans to eliminate and address cases of sexual exploitation and abuse in peacekeeping operations. Afr Secur Rev 14

Klabbers J (1998) Presumptive personality: the European UNION in international law. In: Koskenniemi M (ed) International legal aspects of the European Union. The Hague, Kluwer

Klabbers J (2011) Autonomy, constitutionalism and virtue in international institutional law. In: Collins R, White N (eds) International Organisations and the Idea of Autonomy: Institutional Independence in the International Legal Order. Routledge, $\mathrm{p} 120$

Klabbers J, Wallendahl Å (eds) (2011) Research handbook on the law of international organisations. Edward Elgar, Cheltenham, p 36

Lucey D, Gostin L (2016) The emerging Zika pandemic: enhancing preparedness. JAMA 315(9):865-866

Médecins Sans Frontières (2015) Ebola in West Africa: epidemic requires massive deployment of resources. http://www.msf.org/article/ebola-west-africa-epidemic-requires-massivedeployment-resources. Accessed 21 Oct 2015

Pellet A (2010) The definition of responsibility in international law. In: Crawford J, Pellet A, Olleson $S$ (eds) The law of international responsibility. Oxford University Press, Oxford

Reinalda B, Verbeek B (2011) Policy autonomy of intergovernmental organisations: a challenge to international relations theory? In: Collins R, White N (eds) International Organisations and the Idea of Autonomy: Institutional Independence in the International Legal Order. Routledge

Sari A (2011) Autonomy, Attribution and Accountability. Reflections on the Behrami case. In: Collins R, White N (eds) International Organisations and the Idea of Autonomy: Institutional Independence in the International Legal Order. Routledge, p 257

Seyersted F (1964) International personality of international organisations: do their capacities really depend upon their constitutions? Indian J Int Law 4(1)

Siedner MJ et al (2015) Strengthening the detection of and early response to public health emergencies: lessons from the West African Ebola epidemic. PLOS Med 12:e1001804

The WHO Ebola Response Team (2014) Ebola virus disease in West Africa-The first 9 months of the epidemic and forward projections. New Engl J Med 371:1481 
United Nations (2016a) United Nations treaty collections: Vienna convention on the law of treaties between states and international organisations or between international organisations. https://treaties.un.org/Pages/ViewDetails.aspx?src=TREATY\&mtdsg_no=XXIII$3 \&$ chapter=23\&lang=en. Accessed 21 Mar 2017

United Nations (2016b) United Nations United Nations Haiti Cholera response multi-partner trust fund launched. New York. 14 Oct 2016. Available at: http://mptf.undp.org/factsheet/fund/CLH00

United Nations (2017) UN Haiti Cholera Response Multi-Partner Trust Fund. United Nations, Geneva. Available at: http://mptf.undp.org/factsheet/fund/CLHO0

White N (2005) The law of international organisations, 2nd edn. Manchester University Press, Manchester

WHO (2016) Ebola data and statistics: situation summary, World Health Organisation. http://apps. who.int/gho/data/view.ebola-sitrep.ebola-summary-20150807?lang=en.World. Accessed 7 Aug 2015-24 Oct 2016

World Health Organisation (1999) World Health Organisation Executive Board EB105/30 105th session participation by WHO in the 1986 Vienna convention on the law of treaties between states and international organisations or between international organisations. http://apps.who.int/ gb/archive/pdf_files/EB105/ee30.pdf. Accessed 21 Mar 2016

World Health Organisation (2015) WHO statement on the meeting of the International Health Regulations Emergency committee regarding the 2014 Ebola outbreak in West Africa. http:// www.who.int/mediacentre/news/statements/2014/ebola-20140808/en/. Accessed 7 Oct 2015

World Health Organisation (2015) Report of the Ebola Interim assessment panel. http://www.who. int/csr/resources/publications/ebola/report-by-panel.pdf. Accessed 14 Oct 2015

World Health Organisation (2015) Key events in the WHO response to the Ebola outbreak. http:// www.who.int/csr/disease/ebola/one-year-report/who-response/en/. Accessed 22 Oct 2015 